\title{
Memahami Karakteristik Berliterasi Peserta Didik Di Sekolah
}

\author{
Abd Rahim Mansyur \\ Dosen Tetap Universitas Muslim Indonesia \\ abd.rahimmasyur@gmail.com
}

\begin{abstract}
Abstrak
Pendidikan dibangun dengan pencerahan keaksaraan sebagai pilar dasar kompetensi yang paling dini dibutuhkan peserta didik. Saat ini, upaya pendidikan keaksaraan untuk meningkatkan keterbacaan peserta didik gencar dilakukan melalui literasi yang dicanangkan oleh pemerintah melalui pendidikan formal. Konsep pendidikan literasi berorientasi meningkatkan minat baca peserta didik. Konsep pendidikan ini terkoneksi dengan Gerakan Literasi Sekolah yang dicanangkan oleh pemerintah. Seluruh ekosistem pendidikan harus memiliki pemahaman tentang literasi untuk memaksimalkan pelaksanaannya pada jenjang pendidikan masing-masing. Pelaksanaan pendidikan literasi peserta didik di sekolah mengimplementasikan tiga tahapan untuk menjamin keberlangsungan pendidikan literasi di sekolah, yaitu; melakukan pembiasaan, melakukan pengembangan, dan kesinambungan proses pembelajaran keaksaraan. Tahapan pembiasan, pengembangan, dan pembelajaran dilakukan dengan intensitas pelaksanaan secara berulang ditunjang medium bacaan yang sesuai dengan karakteristik peserta didik untuk mencapai tujuan pelaksanaan pendidikan literasi di sekolah.
\end{abstract}

\section{Kata Kunci: Karakteristik; Literasi; Peserta Didik}

\section{Pendahuluan}

Literasi menjadi program penting di sekolah sebagai usaha untuk mendorong peningkatan kualitas keaksaraan peserta didik. Program ini berkaitan dengan buku dan keterbacaan individu peserta didik dalam mengakses informasi dan pengetahuan. Jika literasi berkaitan penting dengan membaca, maka literasi merupakan masalah pokok maju tidaknya suatu proses pembelajaran di sekolah. Dengan demikian, literasi merupakan kebutuhan dasar yang paling pokok untuk menjadi perhatian sekolah meningkatkan kualitas peserta didik.

Literasi peserta didik didorong melalui kebijakan gerakan literasi di sekolah melalui program Gerakan Literasi Sekolah (GLS) yang dicanangkan oleh pemerintah yang dibina langsung Kementerian Pendidikan dan Kebudayaan RI. Gerakan literasi sekolah merupakan program pemberantasan buta aksara serta berupaya meningkatkan kemampuan membaca peserta didik yang melibat seluruh warga sekolah. Masyarakat juga diberikan ruang untuk berpartisipasi dan berkolaborasi menyukseskan program ini.

Kebijakan tersebut didorong oleh realitas masih minimnya minat baca peserta didik di lingkungan sekolah. Jika dicermati, minimnya minat baca dikarenakan berbagai faktor, diantaranya yaitu; daya dukung bahan bacaan diperpustakaan yang belum memadai, mata pelajaran yang belum diintegrasikan dengan membaca, perkembangan game android yang menyita perhatian peserta didik dari membaca, dan perhatian orang tua yang kurang mengedukasi anak di rumah untuk membaca.

Realitas di sekolah saat ini dapat menjadi pembenaran pendapat tersebut bahwa banyak sekolah dengan minim fasilitas perpustakaan, guru juga belum menjadikan literasi sebagai pokok pembelajaran seolah tugas peningkatan minat baca hanya tugas guru bahasa Indonesia. Padahal aspek membaca merupakan tugas pokok yang penting disadari sebagai misi bersama seluruh guru. Literasi ini semakin melemah di lingkungan keluarga karena orang tua menghabiskan waktu bekerja mencari nafkah. Sehingga, tugas literasi sepenuhnya menjadi tugas besar lembaga pendidikan sekolah. 
Kendala-kendala tersebut membuat merosotnya minat baca secara nasional. Berdasarkan data Tim Penyusun Modul GLN (2016: i) dijelaskan bahwa dalam PIRLS 2011 International Results in Reading, Indonesia menduduki peringkat ke-45 dari 48 negara peserta dengan skor 428 dari skor rata-rata 500 (IEA, 2012). Selanjutnya dijelaskan bahwa uji literasi membaca dalam PISA 2009 menunjukkan peserta didik Indonesia berada pada peringkat ke-57 dengan skor 396 (skor rata-rata OECD 493). Berbeda dengan posisi pada 2012, peserta didik Indonesia pada peringkat ke64 dengan skor 396 (skor ratarata OECD 496) (OECD, 2013). Kurang lebih terdapat 65 negara berpartisipasi dalam PISA 2009 dan 2012 yang mengkhususnkan tes pada keterampilan memahami bacaan. Hasil tes tersebut menunjukkan peserta didik Indonesia barada pada posisi yang masih tergolong rendah.

Data tersebut menunjukkan literasi peserta didik di sekolah harus ditingkatkan melalui berbagai variasi program membaca di sekolah. Pengembangan literasi bagi peserta didik menjadi kebutuhan penting untuk membekali peserta didik kecakapan membaca dini. Apalagi di tengah perkembangan informasi dan teknologi saat ini mengharuskan setiap individu mampu mengakses informasi berbasis teknologis. Oleh karena itu, literasi di sekolah akan mengenalkan peserta didik tidak hanya mengolah informasi melalui buku, namun juga dapat dilakukan melalui teknologi untuk menjadikan pembelajaran lebih menarik.

Kompetensi membaca peserta didik Indonesia yang kalah saing dengan negara lain membutuhkan perhatian besar seluruh ekosistem pendidikan untuk memacu gerakan literasi. Literasi telah lama mengakar dalam Islam, bahkan perintah pertama Rasulullah Saw menerima wahyu di Goa Hira adalah membaca. Dengan demikan, salah satu dasar Islam adalah literasi yang menjadi sumber pencerahan ilahiah. Oleh karena itu, penulis memandang pentingnya mengkaji konsep literasi peserta didik di sekolah. Berdasarkan pendahuluan di atas, maka rumusan masalah penulisan ini, yaitu; "Bagaimanakah karakteristik dan konsep pelaksanaan literasi bagi peserta didik di sekolah?"

\section{Pembahasan}

\subsection{Karakterisk Berliterasi Peserta Didik di Sekolah}

Literasi bukan lagi istilah baru dalam upaya melakukan pembaruan keberaksaraan di Indonesia. Pendidikan literasi menjadi basis edukasi keterbacaan peserta didik di sekolah. Secara sederhana literasi dari segi istilah dapat dipahami sebagai proses belajar mengakses informasi bacaan. Hal ini sebagaimana dijelaskan oleh Kalida dan Mursyid (2014: 5) bahwa istilah literasi mengacu pada huruf sehingga terkadang diterjemahkan sebagai keaksaraan. Ini sesuai dengan makna harfiah bahwa literasi adalah kemampuan membaca dan menulis. Berdasarkan istilah itu, orang yang tidak bisa membaca disebut orang yang buta aksara. Literasi pada dasarnya berkenaan dengan keaksaraan, orang yang memiliki kemampuan membaca dan menulis disebut melek akasara atau melek huruf.

Saat ini, literasi telah berkembang tidak hanya berkaitan dengan bacaan tertulis tapi juga berbasis teknologis. Pendidikan literasi dilakukan berdasarkan jenis tingkatannya. Clay dan Ferguson (Wiedarti, dkk, 2016: 7) mengemukakan jenis literasi menjadi; (a) literasi dini, (b) literasi dasar, (c) literasi perpustakaan, (d) literasi media, (e) literasi teknologis, dan (f) literasi visual.

\section{a. Literasi Dini}

Literasi dini menitikberatkan kemampuan menyimak peserta didik. Penyimakan ini untuk memahami bahasa lisan dan berkomunikasi melalui visual gambar dan lisan. Pembentukannya dilakukan melalui pengalaman peserta didik melalui proses berkomunikasi menggunakan bahasa ibu. Penggunaan bahasa ibu sangat menentukan kecakapan literasi peserta didik sebagai fondasi perkembangan literasi dasar.

Usia dini biasa disebut juga sebagai golden age (usia emas). Penyediaan bahan bacaan harus memerhatikan karakterisik peserta didik. Berkaitan dengan hal ini sebagaimana Aisyah, dkk (2010) mengemukakan tujuh karakteristik anak usia dini, yaitu; (1) memiliki rasa ingin tahu yang besar, (2) merupakan pribadi yang unik, (3) suka berfantasi dan berimajinasi, (4) masa paling potensial 
untuk belajar, (5) menunjukkan sikap egosentris, (6) memiliki rentang daya konsentrasi yang pendek, dan (7) sebagai bagian dari makhluk sosial.

Literasi yang dilakukan akan sangat membantu pertumbuhan dan perkembangan kecerdasan bahasa peserta didik. Melalui literasi akan menstimulus perkembangan mental anak dengan pengenalan lingkungan dan penggunaan bahasa ibu yang mereka pahami. Literasi dini dapat digunakan sebagai program untuk menstimulus enam kecerdasan bagi anak secara dini, yaitu; pengenalan agama dan moral, fisik motorik, pengembangan kognisi, stimulus sosial-emosional, dan pembentukan daya seni.

\section{b. Literasi Dasar (Basic Literacy)}

Literasi dasar menumbuhkan kemampuan mendengarkan, berbicara, membaca, menulis, dan berhitung. Pada tahapan literasi dasar ini kekampuan analisis mulai diberikan dengan memperhitungkan serta memersepsi informasi. Peserta didik juga diajari mengomunikasikan dan mengembangkan informasi dengan menggambarkan berdasarkan pemahaman dan kesimpulan personal.

Jenis literasi dasar ini merupakan tahap lanjutan literasi dini di mana perserta didik dibentuk melalui pembiasaan literasi. Membaca dapat dilakukan pada waktu tertentu sebagai dasar menuju literasi menulis dan berhitung. Aspek membaca dapat dilakukan melalui tahapan permulaan dan tahapan menulis lanjutan dengan menggunakan berbagai pendekatan dan teknik dalam membaca.

Tujuan membaca permulaan diarahkan untuk membentuk memori visual peserta didik tentang huruf, kata, dan kalimat sebagai suatu bangunan grafis. Kemudian memasuki fase pengucapakan kata dengan menekankan aspek pemaknaan terhadap kata dan kalimat yang diperlajari. Guru harus memahami literasi dasar untuk memaksimalkan tingkat keterbacaan peserta didik di sekolah.

Steinberg (Susanto, 2011: 83) menjelaskan membaca permulaan sebagai suatu proses membaca yang diajarkan secara terprogram untuk anak prasekolah. Lebih lanjut dijelaskannya bahwa program ini merupakan perhatian pada perkataan-perkataan utuh dan bermakna sesuai konteks anak-anak dan bahan yang diberikan melalui permainan dan kegiatan menarik yang menjadi selingan pembelajaran.

\section{c. Literasi Perpustakaan (Library Literacy)}

Literasi perpustakaan (Librari Literacy) memberikan bekal pengetahuan dan pemahaman bagi peserta didik di sekolah mengenali dan membedakan ragam bahan perpustakaan. Dengan demikian, peserta didik akan mampu membedakan antara bahan bacaan fiksi dan nonfiksi. Peserta didik juga diberikan pemahaman tentang manfaat berbagai koleksi bahan perpustakaan dan penataannya pada perpustakaan.

Kedudukan perpustakaan sekolah sangat membantu proses berliterasi peserta didik sekolah. Sebagaimana dikemukakan Supriyadi (Bafadal, 2015: 4) bahwa perpustakaan sekolah sebagai sebuah tempat di lingkungan sekolah untuk menunjang proses belajar di sekolah. Dengan demikian, perpustakaan menjamin jalannya proses literasi perpustakaan pada peserta didik.

Pemahaman literasi perpustakaan ini akan sangat membantu peserta didik memahami selukbeluk pelayanan di perpustakaan. Oleh karena itu, ketersediaan sarana perpustakaan di sekolah merupakan sarana vital untuk menunjang proses pembelajaran literasi. Kegiatan dalam bentuk kunjungan ke perpustakaan daerah maupun perpustakaan kampus juga dapat dilakukan untuk lebih memotivasi peserta didik melihat secara langsung situasi perpustakaan di luar sekolah.

\section{d. Literasi Media (Media Literacy)}

Literasi media membentuk kemampuan peserta didik memahami dan menganalisis serta membangun pemahamannya tentang media. Saat ini terdapat berbagai macam bentuk media seperti media cetak, media elektronik seperti radio dan televisi, media digital seperti internet dan medsos berbasis android. Literasi media memberikan standar etis bagaimana seluruh media tersebut dapat 
diakses dan dipergunakan sesuai kebutuhan perserta didik. Pendidikan literasi media ini sangat penting agar peserta didik tidak terjebak pada berbagai akses negatif yang disajikan oleh media.

Kehadiran media massa memberikan banyak dampak pada kehidupan saat ini secara positif maupun negatif. Media pertelevisian misalnya, dapat menyajikan banyak kemasan iklan dan film diluar batas usia. Terlebih lagi media internet berbasis android yang menyajikan semua bentuk konten di dalamnya bisa membahayakan peserta didik. Di sinilah peranan pendidikan literasi media di sekolah dasar untuk menanamkan bagaimana mengakses media secara bijak kepada peserta didik. Akhir-akhir ini, dengan adanya media game online berbasis android juga telah merenggut banyak nyawa anak usia sekolah dasar, sehingga dibutuhkan kolaborasi orang tua melakukan pendampingan terhadap anak di rumah.

\section{e. Literasi Teknologi (Technology Literacy)}

Pendidikan literasi teknologi mengasah kemampuan peserta didik memahami teknologi. Saat ini semua peserta didik akrab dengan dengan teknologi dalam kehidupan mereka. Bahkan, interaksi mereka dengan teknologi lebih intens daripada interaksi dengan kedua orang tua di rumah. Sekolah harus mampu memberikan pendampingan edukasi tentang etika dan etiket dalam menggunakan teknologi.

Tahapan selanjutnya peserta didik dapat diberikan pemahaman tentang bagaimana menggunakan teknologi untuk kebutuhan belajarnya. Hal ini untuk lebih mengorientasikan peserta didik mengoperasikan teknologi, mengakses kebutuhan data tugas internet, dan mampu menyimpannya dalam bentuk fail di komputer. Dalam laman internet terdapat banyak iklan negatif yang dapat mengganggu peserta didik, sehingga harus diberikan pemahaman positif mengelola informasi yang ada untuk kebaikan diri peserta didik.

\section{f. Literasi Visual (Visual Literacy)}

Pendidikan literasi visual dapat menumbuhkan daya imajinasi dan kritis peserta didik. Literasi visual menopang pembelajaran literasi media dan literasi teknologi. Tujuan literasi visual untuk mengembangkan kemampuan peserta didik memanfaatkan materi visual serta audiovisual secara kritis. Tahapan proses pembelajaran ini dapat menggunakan visual gambar maupun elektronik untuk lebih menstimulus daya imajinasi kritis peserta didik dalam menganalisis dan memahami.

Pendidikan literasi visual menggunakan multimedia. Dalam pelaksanaan pembelajaran guru mengkombinasikan media elektronik, teks, gambar, video dan animasi untuk dapat mengembangkan potensi peserta didik melalui pemilihan kata yang relevan sesuai gambar, mengenali dan memahami pesan pada gambar, menyusun kata sesuai gambar, serta mampu melafalkan kata-kata. Untuk kelas tinggi dapat dikembangkan pada tahapan berani mengatraksi dan membaca di depan kelas.

Pendidikan literasi merupakan proses pencerahan keaksaraan untuk menstimulus potensi membaca dan mengasah keterampilan menulis peserta didik. Proses ini sangat mendasar karena akan menyiapkan peserta didik mengakses berbagai informasi secara mandiri dan mampu menggunakan informasi itu secara positif. Tingkat pendidikan sekolah dasar/MI berada pada level literasi dini dan dasar (Basic Literacy). Meskipun demikian, harus diditunjang dengan jenis literasi lainnya dalam bentuk yang lengkap maupun yang lebih sederhana untuk memaksimalkan transmisi dua jenis literasi paling dasar tersebut.

Pendidikan literasi sangat bermanfaat bagi peserta didik. Untuk itu, harus ditunjang dengan beberapa tahapan pelaksanaan literasi di sekolah. Beberapa tahapan pelaksanaan tersebut dikemukakan oleh Lipton dan Hubble (2016: 132) mencakup tiga komponen proses penting, yaitu;

1) Pembiasaan, yaitu penumbuhan minat baca melalui kegiatan lima belas menit membaca.

2) Pengembangan, yaitu menstimulus kemampuan literasi melalui kegiatan menanggapi buku pengayaan.

3) Pembelajaran, yaitu meningkatkan kemampuan literasi di semua mata pelajaran dengan menggunakan buku pengayaan dan strategis membaca di semua mata pelajaran. 
Berdasarkan penjelasan di atas, dapat disimpulkan bahwa penerapan pendidikan literasi di sekolah akan memberikan pengalaman yang kaya kepada peserta didik karena membiasakan mereka untukmenginterpretasi dengan cara berpendapat, berkolaborasi, memberikan peserta didik pengalaman berkonvensi dan pengetahuan kultural. Selain itu, peserta didik juga diajarkan memecahkan masalah dan melakukan refleksi yang bisa diucapkan dengan bahasa melalui diskusi yang dipandu oleh guru di dalam pembelajaran.

\subsection{Pelaksanaan Literasi Peserta Didik Madrasah Ibtidaiyah}

Pelaksanaan gerakan literasi peserta didik mengacu pada pelaksanaan gerakan literasi sekolah secara nasional. Pendidikan literasi di tingkat sekolah dasar/MI dilaksanakan secara bertahap untuk menjamin keberlangsungannya. Dalam buku Panduan Gerakan Literasi Sekolah di Sekolah Dasar (Dirjendikdasmen, 2016: 10) dikemukakan tiga tahapan pelaksanaan gerakan literasi sekolah yaitu tahap pembiasaan, tahap pengembangan, dan tahap pembelajaran. Tahapan ini dimaksudkan untuk memaksimalkan proses literasi serta mencapai kualitas keterbacaan dan budaya literasi peserta didik.

\section{a. Tahap Pembiasaan Berliterasi}

Tahapan pelaksanaan kegiatan pembiasaan gerakan literasi bertujuan menumbuhkan minat peserta didik terhadap bahan bacaan dan kegiatan membaca. Minat terhadap membaca perlu dipicu melalui proses pembiasaan dengan cara menggunakan media pembelajaran dan strategi pembudayaan literasi di sekolah. Kegiatan yang dilakukan diantaranya, sebagai berikut.

(1) Lima belas menit membaca setiap hari sebelum jam pelajaran. Peserta didik dapat diberikan keleluasaan untuk membaca nyaring atau membaca dalam hati. Peserta didik juga bisa membaca secara berkelompok.

(2) Sekolah harus menyediakan lingkungan sekolah yang dapat menginspirasi peserta didik membaca melalui penyediaan mading maupun taman baca.

(3) Sarana penunjang perpustakaan harus disiapkan dengan kelengkapan bahan perpustakaan yang sesuai dengan dunia peserta didik.

(4) Desain taman baca dan sudut kreatif untuk menarik minat peserta didik menghabiskan jam istirahat di tempat yang kaya nuansa literasi.

(5) Pengadaan sarana penunjang pemrograman dan membudayakan "nonton bareng" film-film Islami dan film bertema sosial dan sejarah. Hal ini dimaksudkan untuk menunjang literasi visual bagi peserta didik.

\section{b. Tahap Pengembangan Berliterasi}

Kegiatan literasi tahap pengembangan bertujuan untuk mempertahankan minat terhadap bacaan dan terhadap kegiatan membaca, serta meningkatkan kelancaran dan pemahaman membaca peserta didik (Dirjendikdasmen, 2016: 27). Pada tahapan ini guru tidak bisa membiarkan peserta didik yang belum bisa mandiri dan mendisiplikan diri ketika membaca. Oleh karena itu, guru harus hadir selain sebagai mentor juga dapat mendisiplinkan peserta didik membaca.

Tahapan pegembangan berliterasi tersebut dikemas dalam berbagai bentuk kegiatan kreatif. Dalam buku Panduan Gerakan Literasi Sekolah di Sekolah Dasar (Dirjendikdasmen, 2016: 31-37) dikemukakan langkah-langkah membaca pada tahapan pengembangan yaitu; membacakan nyaring interaktif (Interactive Read Aloud), membaca terpadu (Guided Reading), membaca bersama (Shared Reading), dan membaca mandiri (Independent Reading).

\section{1) Membacakan Nyaring Interaktif (Interactive Read Aloud)}

Kegiatan membacakan nyaring dilakukan secara interaktif sehingga kegiatan membaca menjadi ruang dialektis antara guru, peserta didik, dan bahan bacaan. Guru diharapkan tidak terlalu aktif dalam proses kegiatan ini untuk lebih memberikan ruang kepada peserta didik membaca, menyimak bacaan, dan menanggapi isi bacaan yang lain secara lebih aktif. Oleh karena itu, guru hanya memandu dan mencontohkan kemudian mengajak peserta didik melakukan apa yang dicontohkan. Membaca nyaring semacam ini akan efektif bila digunakan untuk menstimulus pemahaman kosakata baru peserta didik. 


\section{2) Membaca Terpandu (Guided Reading)}

Membaca terpadu dilakukan secara berkelompok. Guru dianjurkan membagi peserta didik menjadi beberapa kelompok untuk melakukan kegiatan membaca. Dalam desain membaca semacam ini, proses penyimakan terhadap kelompok lain biasanya dilakukan untuk dilanjutkan dengan diskusi untuk mendengarkan bagaimana tanggapan kelompok lain terhadap isi bacaan yang disampaikan. Guru menentukan tujuan atau progres bacaan yang ingin dicapai dan mendampingi untuk membantu perserta didik memahami isi bacaan sekaligus mengamati perkembangan peserta didik membaca.

\section{3) Membaca Bersama (Shared Reading)}

Membaca bersama dilakukan oleh guru dengan peserta didik. Tujuannya untuk mengenalkan bahan bacaan dan memberikan pemahaman membaca kepada peserta didik. Membaca bersama secara sederhana dapat dimaknai sebagai interaksi antara guru sebagai orang dewasa dengan anakanak sebagai peserta didik.

Jenis bahan bacaan yang digunakan dalam membaca bersama diutamakan buku cerita anak, sehingga bahan bacaan cerita yang dekat dengan kehidupan anak akan mampu menarik perhatian peserta didik. Akan tetapi, model membaca bersama dirasakan minim ruang bagi anak karena terfokus pada guru sebagai model. Untuk itu, perlu dilakukan strategi yang fleksibel dengan menjadikan peserta didik yang sudah memiliki kecakapan membaca cerita untuk dapat menjadi model bercerita.

\section{4) Membaca Mandiri (Independent Reading)}

Membaca mandiri bertujuan memberikan peluang kepada peserta didik memilih sendiri bahan bacaan yang disenangi kemudian dilanjutkan dengan membaca mandiri di tingkatan sekolah dasar/MI. Kegiatan ini bisa dilakukan di pojok baca atau perpustakaan sekolah. Guru diharapkan menjadi observer untuk mengamati keseriusan peserta didik membaca. Kegiatan membaca mandiri juga bisa dilakukan di rumah. Untuk itulah, peran serta orang tua harus terkolaborasi dengan gerakan literasi sekolah.

Berdasarkan penjelasan di atas, dapat dipahami bahwa aspek membaca merupakan kegiatan yang dilakukan secara bervariasi pada tahap pengembangan. Membaca bertujuan memberikan suasana kepada pembelajar banyak nuansa kompleks. Seperti dikemukakan oleh Blanton, dkk (Rahim, 2008: 11) bahwa membaca bertujuan untuk mencapai kesenangan. Membaca dapat memperbarui pengetahuan tentang suatu topik dan mampu mengaitkan informasi baru dengan informasi yang telah diketahui. Dengan membaca seseorang dapat memperkaya informasi untuk laporan lisan atau tertulis. Membaca juga bertujuan menampilkan suatu eksperimen teks dan mengaplikasikan suatu informasi yang diperoleh dari suatu teks.

Proses membaca yang dilakukan dapat dipengaruhi oleh banyak faktor secara fisiologis, psikologis, maupun lingkungan. Sehingga, sekolah harus mampu mengidentifikasi berbagai kemungkinan gangguan tersebut untuk mengemas pembelajaran lebih menarik bagi peserta didik pada setiap tingkatan sekolah.

c. Tahap Pembelajaran

Minat literasi selalu mengalami pasang surut. Hal ini terjadi pada setiap orang secara umum. Oleh karena itu, minat membaca peserta didik di sekolah harus dirawat melalui tahapan pembelajaran. Dimyati dan Mudjiono (Syaiful Sagala, 2011: 62) mengemukakan pembelajaran sebagai kegiatan guru yang dilaksanakan secara terprogram dengan desain intruksional untuk belajar secara aktif yang menekankan ketersediaan sumber belajar.

Dengan demikian, maka pembelajaran menjadi momentum interaksi penting antara guru dan peserta didik di sekolah, sehingga sangat menentukan kesinambungan suatu transformasi pengetahuan, termasuk transformasi literasi. Sebagaimana dijelaskan dalam buku Panduan Gerakan Literasi Sekolah di Sekolah Dasar (Dirjendikdasmen, 2016: 57) bahwa kegiatan literasi 
pada tahap pembelajaran bertujuan untuk mempertahankan minat peserta didik terhadap bacaan dan terhadap kegiatan membaca, serta meningkatkan kecakapan literasi peserta didik melalui bukubuku pengayaan dan buku teks pelajaran.

Kegiatan literasi pada proses pembelajaran dilakukan dengan berbagai variasi kegiatan membaca dan menulis serta memilih bahan belajar yang medorong efisiensi literasi pada tahap pembelajaran. Dianjurkan pula menggunakan buku pengayaan untuk kegiatan menulis kreatif bagi kelas tinggi. Seluruh komponen dalam pendidikan literasi peserta didik Madrasah Ibtidaiyah penting dimaksimalkan untuk mencapai kualtas keterbacaan aksara pada peserta didik.

Dalam pelaksanaan tersebut, penting diperhatikan prinsip-prinsip yang dikemukakan oleh Lipton dan Hubble (2016: 124), sebagai berikut.

1) Literasi melibatkan interpretasi

Penulis maupun pembaca serta pembaca maupun pendengar sama-sama berpartisipasi dala tindak interpretasi. Dengan demikian, guru dan peserta didik dalam pembelajaran merupakan pembaca dan pendengar yang sama-sama memiliki interpretasi terhadap bahan bacaan yang akses selama berliterasi.

2) Literasi melibatkan kolaborasi

Literasi merupakan proses pelibatan kolaborasi yang lebih dari dua pihak. Kerjasama ini melibatkan guru, peserta didi, dan orang tua dalam upaya mencapa tujuan berliterasi.

3) Literasi melibatkan konvensi

Melibatkan konvensi maksudnya orang-orang membaca dan menulis atau menyimak dan berbicara itu ditentukan oleh konvensi atau kesepakatan kulturalyang berkembang melalui penggunaan dan dimodifikasi untuk tujuan-tujuan individual. Konvensi disini mencakup aturanaturan bahasa baik lisan maupun tertulis. Dengan, demikian maka pengembangan melalui pembelajaran mengikuti kurikulum dan kemanisme yang berlaku secara umum pada setiap sekolah.

4) Literasi melibatkan pengetahuan kultural

Berliterasi secara kultural berfungsi menjadi subsistem sikap, keyakinan, kebiasaan, cita-cita, dan terjelma menjadi nilai tertentu pada diri peserta didik. Hal inilah yang akan berkembang menjadi kaakter mulia jika berliterasi benar-benar telah menjadi kultur yang menjiwa pada diri peserta didik.

5) Literasi melibatkan pemecahan masalah

Mengakses informasi melibatkan proses pembacaan teks yang kompleks. Peserta didik akan diperhadapkan pada kata-kata dan berbagai variasi linguistik. Oleh karena itu, proses menyimak dan membaca tentunya proses menyelami keterhubungan antarkata, frase, dan kalimat serta unitunit makna lainnya. Proses berliterasi merupakan suatu tahap pemecahan masalah.

6) Literasi melibatkan refleksi dan refleksi diri

Berliterasi bagi peserta didik di sekolah membantu mereka merefleksi bahasa yang mereka pelajari yang dikaitkan dengan dunia dan diri mereka sendiri. Proses ini kemudian berlanjut pada tahapan komunikasi memikirkan apa yang dipelajari peserta didik dan memikirkan tujuan apa yang akan diambil dari proses berliterasi di sekolah.

7) Literasi melibatkan penggunaan bahasa

Prinsip ini menunjukkan berliterasi bagi peserta didik mengasah kecakapan kebahasaan mereka selama proses mengakses informasi melalui membaca maupun dalam rangkaian kegiatan lainnya.

Berdasarkan penjelasan tersebut di atas, dapat disimpulkan bahwa kegiatan literasi sekolah di tingkat sekolah harus dilakukan secara tersistem dan berkesinambungan dengan tetap memerhatikan prinsip pendidikan literasi adalah literasi melibatkan interpretasi, kolaborasi, konversi, pengetahuan kultural, pemecahan masalah, refleksi diri, dan melibatkan penggunaan 
bahasa. Pelaksanaannya harus didukung dengan sarana yang memadai. Selain itu, penyediaan sarana bahan bacaan harus menarik dan dekan dengan dunia peserta didik. Kegiatan membaca yang dilakukan pula harus kreatif dengan dukungan berbagai pendekatan dan strategi dalam membaca. Pealaksanaan berliterasi ini harus terkolaborasi dengan seluruh komponen pendidikan, khususnya orang tua di rumah. Bila perlu, harus dibentuk forum orang tua wali berliterasi untuk berkolaborasi dengan guru dengan tugas khusus mengawal aktivitas membaca anak di rumah.

\section{Kesimpulan}

Berdasarkan pembahan di atas, dapat dirumuskan kesimpulan sebagai berikut.

Literasi bagi peserta didik di sekolah sangat penting untuk mengasah keaksaraan dan keterbacaan. Literasi bagi peserta didik menjadi suplemen rendahnya minat baca yang menunjukkan bahwa pendidikan selama ini belum maksimal mengembangkan kompetensi dan minat peserta didik terhadap pelbagai pengetahuan. Oleh karena itu, untuk menerapkan pendidikan literasi kepada peserta didik dibutuhkan pengetahuan tentang konsep literasi dan pengetahuan tentang karakteristik peserta didik.

Pendidikan literasi peserta didik mengacu pada program Gerakan Literasi Sekolah secara nasional yang melibatkan seluruh ekosistem pendidikan. Pendidikan literasi di sekolah dilaksanakan dalam tiga tahapan untuk menjamin keberlangsungannya. Tiga tahapan ini dimaksudkan untuk memaksimalkan proses literasi serta mencapai kualitas keterbacaan dan budaya literasi peserta didik. tiga tahapan tersebut ialah; pembiasaan, pengembangan, dan pembelajaran.

Program peserta didik berliterasi harus didukung seluruh ekosistem sekolah, terkhusus orang tua peserta didik. Hal ini dimaksudkan agar terbangunnya koneksi sinergitas dan kolaborasi antara sekolah dan orang tua. Selain itu, kecenderungan peserta didik berliterasi yang fluktuatif mengharuskan partisipasi orang tua di rumah untuk mengawal serta anak-anak tetap membudayakan literasi, khsusunya membaca, di rumah. 


\section{DAFTAR PUSTAKA}

Aisyah, Siti, dkk. 2010. Perkembangan dan Konsep Dasar Pengembangan Anak Usia Dini. Jakarta: Universitas Terbuka.

Dirjendikdasmen. 2016. Panduan Gerakan Literasi Sekolah di Sekolah Dasar. Jakarta: Dirjendikdasmen.

Farida Rahim. 2008. Pengajaran Membaca di Sekolah Dasar. Jakarta: Bumi Aksara.

Kalida, Muhsin dan Mursyid, Moh. 2014. Gerakan Literasi Mencerdaskan Negeri, Cet.1. Yogyakarta: CV. Aswaja Pressindo.

Lipton, Laura dan Hubble, Debora. 2016. Sekolah Literasi, Perencanaan dan Pembinaan, cet. I. Bandung: Nuansa Cendekia.

Sagala, Syaiful. 2011. Konsep dan Makna Pembelajaran. Bandung: Alfabeta.

Susanto, A. 2011. Perkembangan Anak Usia Dini. Jakarta: Kencana.

Wiedarti, Pangesti dkk. 2016. Desain Induk Gerakan Literasi Sekolah. Jakarta: Direktorat Jenderal Pendidikan Dasar dan Menengah Kementerian Pendidikan dan Kebudayaan, 2016, diakses pada 7 Desember 2019. 